\title{
Creating the future: towards an integrated system for photonics education and training
}

\section{Tuan-Kay Lim}

Tuan-Kay Lim, "Creating the future: towards an integrated system for photonics education and training," Proc. SPIE 9663, Eighth International Topical Meeting on Education and Training in Optics and Photonics, 96630R (6 October 2003); doi: 10.1117/12.2207480

SPIE Event: Eighth International Topical Meeting on Education and Training in Optics and Photonics, 2003, Tucson, Arizona, United States 


\title{
Creating the Future: Towards an Integrated System for Photonics Education and Training
}

\author{
Tuan-Kay Lim \\ Photonics Research Centre, School of Electrical and Electronic Engineering \\ Nanyang Technological University, Nanyang Avenue, Singapore 639798 \\ etklim@ntu.edu.sg
}

\begin{abstract}
A critical factor for realizing the steady and sustainable growth of the optics industry in Singapore is an adequate and steady supply of qualified personnel at all levels. In this paper, the formation of the National Alliance for Photonics Education and Training (NAPET) is reported. The main goal of NAPET is to develop an integrated system for photonics education and training in Singapore. The important role of global networking and cooperation will also be discussed. (C) 2003 Optical Society of America

OCIS codes: (999.9999) Optics education; (000..2060) Education; (350.4600) Optical engineering
\end{abstract}

\section{Introduction}

In recognizing the growth potential of the global market in optics and photonics Singapore is determined to accelerate the growth of the optics industry. A critical factor for realizing the steady and sustainable growth of the optics industry is an adequate and steady supply of qualified personnel at all levels. To fulfill this need, the National Alliance for Photonics Education and Training (NAPET) of Singapore was formed in March 2003.

In this paper, we will first review the key events in the development of photonics in Singapore in the past 10 years and the current state of photonics education and training in Singapore. The formation of NAPET, its mission and plan of activities will be elucidated. In particular, it is emphasized that a key factor in determining the success of NAPET is to further develop and strengthen our collaboration with other research centers and organizations, both locally and internationally, because it will facilitate the sharing of resources and experiences. Accordingly, the role of NAPET in the proposed Global Photonics Education Network (GPEN) will be discussed.

\section{Development of Photonics in Singapore}

Development of photonics in Singapore had been lagging behind as compared to the more well-developed countries. Nevertheless, in the past ten years, the pace of development has quickened, notably through a series of key events as summarized in Table 1. I have been privileged to have the opportunity to play a key role in these events as noted in the table, in the brackets under the name of each event. Through all these endeavors we have established close relationships with the optics communities in Singapore as well as a global network for international cooperation. In particular, they have culminated to the formation of the National Alliance for Photonics Education and Training (NAPET) in March 2003, as elucidated in the next section.

\section{Development of an Integrated System for Photonics Education and Training}

In this section, before the discussion on the formation and mission of NAPET, we will first provide an overview on the current state of photonics education and training in Singapore. It is pointed out that due to the highly competitive, structured, and standards-based curricula for the primary schools, secondary schools, and junior colleges, education in photonics has mainly be provided through project-based learning and to a selected group of students. To provide the learning opportunities for students at all levels an integrated education and training system consisting of a variety of innovative, flexible programs must be developed. These programs should also be designed to prepare the students for greater success in higher education and career development.

The design and implementation of the photonic education and training programs for students must build on the strong science and mathematics foundation that has been the hallmark of the Singapore education system. It must

Eighth International Topical Meeting on Education and Training in Optics and Photonics,

edited by Barry L. Shoop, Grover Swartzlander Jr., Proc. of SPIE Vol. 9663, 96630R

(c) 2003 SPIE, OSA, ICO · doi: $10.1117 / 12.2207480$ 
also capitalize on the schools' excellent infrastructures, especially the information technology and education resources. Furthermore, with the multi-disciplinary nature of photonics the new curricula could be incorporated to physics, chemistry, and biology subjects. The wide range of applications of photonics would also provide the students an excellent opportunity to learn the principles and practice of engineering. This will not only enrich the students' learning experience, but will also prepare them for advancement to a professional career through tertiary education. The formation of NAPET has enabled the whole optics and photonics community to work together to achieving these goals.

\subsection{Current State of Photonics Education and Training in Singapore [1]}

(1) Project-Based Learning

In the past four decades Singapore has established an education system that serves well the developments of the major industry clusters, including semiconductor, electronics, and petrochemicals. In Fig. 1, an overview of the Singapore education system from Primary to University Education is shown. Within this system, curricula of primary, secondary, and junior college education have been highly competitive, structured, and standards-based [2]. As a consequence, coverage on optics has been limited to simple geometrical and physical optics. It has been difficult to incorporate modern optics and photonics into the formal curricula. Accordingly, project-based learning is one of the effective ways for cultivating the interest of students in optics and photonics, both at the secondary and postsecondary levels. At the senior secondary and junior college (grades 9 to 12) level, the various mentoring schemes have been very successful. In these schemes, faculty members from universities and polytechnics serve as mentors for research projects during school vacation periods. Students are required to submit a technical report and make an oral presentation at the end of the project. With the establishment of the Photonics Exploration Lab at the Raffles Institution and the Photonics Learning and Research Centre at The Chinese High School in 2000, students has been able to engage in project-based learning during term times as well.

At the polytechnics and universities, students have been involved in optics- and photonics-related projects during the In-House Practical Training (IHPT) period, the Industrial Attachment (IA) period, and in their final year of study. For the IHPT, students work for up to 8 weeks in the laboratories on campus under the supervision of academic staff. During the industrial attachment period students work full time at private companies, research institutes/centers, or government labs for up to 6 months. On the other hand, the final year projects cover the whole final year of study, with many projects sponsored by industry. Therefore, these projects provide excellent opportunities for students to immerse in the academic and industrial research and development environments.

\section{(2) Special Training Programs}

To accelerate the pace of manpower development for the industry, the Singapore Economic Development Board (EDB) [3] has been working with the tertiary institutions on several special manpower programs. Under these programs, companies co-sponsor trainees for specialization in a certain area of photonics, and the trainees are required to work with the companies upon completion of the training. In addition, EDB also offers other programs, including the Training and Attachment Program (TAP), the Research and Training Program (RTP), and the Postgraduate Manpower Program (PMP). Specifically, TAP provides assistance to private companies for training their staff in new areas such as optical networking; RTP recruits and places qualified trainees in local research institutes/centers or tertiary institutions for on-the-job training before they go to work in the industry; and PMP provides sponsorships for graduate students in optics at the Nanyang Technological University (NTU) and the National University of Singapore (NUS).

\section{(3) Formal Education Programs}

The development of formal curricula at the polytechnics and universities has also been intensified in the past few years. At the technician and technologist level, the four polytechnics are offering elective subjects or modules, covering lasers, optoelectronics, fiber optics communications, and optical networking. At the undergraduate level, NUS offers electives in machine vision, modern optics, optoelectronics, and optical communications, as well as a minor on optics in information technology. On the other hand, NTU launched a Final Year Specialization program in photonics in July 2000, offering final year students a range of subjects including laser engineering, fiber optics communications, optoelectronics, optical system and instrumentation, photonic instrumentation design, and photonic system design. Now going into its fourth year, this program has been very well received. 
At the graduate studies level, the number of masters and Ph.D. students has been increasing in recent years. The areas of research include lasers, optoelectronics, fiber optics, fiber optic communications, fiber optics sensors, biomedical imaging and instrumentation, optical signal processing, optical storage, and displays.

\subsection{Mission of the National Alliance for Photonics Education and Training (NAPET)}

The conception for the formation of the National Alliance for Photonics Education and Training (NAPET) was first revealed at the Forum on Education and Training in Optics and Photonics held on 2 December 1999 in Singapore. The idea was further developed through the following years [1,4-6], and has culminated to the actual formation of NAPET at its inaugural meeting held on 29 March 2003 at the Singapore Economic Development Board [7].

NAPET is a national alliance of high schools, technical training institutes, tertiary institutions, research institutes, the industry, government bodies, and professional societies. The mission of NAPET is to establish Singapore as a centre of excellence for education and training in optics and photonics, through the development of an integrated education and training system that is vital for the continual development of workforce and sustainable growth of the photonics industry in Singapore. To realize this mission, the objectives of this alliance are formulated as follows:

- To identify the needs for manpower education and workforce development in optics and photonics;

- To develop comprehensive, structured programs for education and training of researchers and scientists;

- To develop comprehensive, structured programs for education and training of technicians and technologists;

- To develop outreach programs for students, parents, teachers, school counselors, and the public;

- To develop continuing education and training programs and workshops for teachers, counselors, parents, working professionals, administrative personnel, policy makers, and the public;

- $\quad$ To assess, implement, evaluate, and improve these programs.

To achieve these objectives appropriate committees and working groups will be formed. Programs developed and experience gained elsewhere are valuable resources and references for developing our own programs. More importantly, the dedication and collaboration of the whole optics community in Singapore are critical for the success of this endeavor. In the following, we will focus our discussion on the development of the following programs:

- Education programs for high schools, institutes of technical education, and tertiary institutions

- Training programs for teachers, technicians, engineers, and administrators

- Outreach programs for students, parents, teachers, counselors, administrators, policy makers, and the general public

Currently, there is an urgent need for the development of training programs for the industry and outreach programs to promote the awareness and understanding of photonics for students and the public. In the education system, as described in the previous section, photonics education has mainly been concentrated at the senior undergraduate and postgraduate levels, and specialized training programs in the polytechnics. At the high school level, education in photonics has been facilitated through project-based learning. To provide the learning opportunities for students at all levels an integrated education and training system must be developed. In particular, there is an urgent need for the development of photonics curricula for high school and technical training institute students. The formation of NAPET has enabled the whole optics and photonics community to work together to achieving these goals.

To expedite the development of photonics education and training programs at the high school and technical institute levels, teachers training workshops will be organized. Through these workshops, working groups for curriculum developments will be formed. Academic staff from universities and polytechnics, as well as research scientists and engineers from the industry and research institutes will play important roles for the organization of the workshops.

To facilitate the development of relevant programs for the photonics industry, NAPET will conduct a survey on the training needs of the industry and the expertise residing in the education institutions and research institutes. This survey is the first step towards the creation of a database that could be used for matching industry needs to the pool of expertise, thereby enabling more efficient and effective development of training programs.

Over the past ten years, we have established a global network with a wide range of organizations and institutions. The formation of NAPET will further enhance and expand this network that will provide invaluable experience and resources for the development of the education and training programs in Singapore. More details are provided in the next section. 


\section{Collaboration with Other Organizations and Institutions}

As stated before, one of the key factors for our success is the collaboration with other organizations and institutions. Accordingly, in this section we will provide a brief account on the potential collaborators, both local and international.

\subsection{Collaborators in Singapore}

Within the Nanyang Technological University (NTU) and the National Institute of Education (NIE) [7] there are many academic groups and research or technology centers that could be our collaborators. Some of them are more closely related to our work as listed below:

- Centre for Educational Development (CED), NTU

- $\quad$ Centre for Continuing Education (CCE), NTU

- $\quad$ Centre for Research on Small Enterprise Development (CRSED), NTU

- $\quad$ Office of Professional Attachment (OPA), NTU

- Instructional Science Group, NIE

- $\quad$ Science and Technology Education Group, NIE

- $\quad$ Natural Sciences Group, NIE

- $\quad$ e-Learning Competency Centre (ECC), NIE

Outside of the campus, we could also collaborate with many organizations, including the Ministryof Education (MOE), Ministry of Manpower (MOM), members of the Singapore Centre of Photonics Excellence (SCOPE) [3], and professional societies as listed below:

Members of SCOPE (besides NTU)

- $\quad$ National University of Singapore (NUS)

- $\quad$ Economic Development Board (EDB)

- $\quad$ PSB Corporation

- $\quad$ Singapore Institute of Manufacturing Technology (SIMTech)

- $\quad$ Data Storage Institute (DSI)

- Institute of Microelectronics (IME)

- Institute for Materials Research and Engineering (IMRE)

Professional Societies:

- $\quad$ SPIE Singapore Chapter

- IEEE Singapore Section

- Institute of Physics, Singapore (IPS)

- Institute of Engineers, Singapore (IES)

\subsection{International Collaborators}

As stated before, over the past ten years we have established a global network with a wide range of organizations and institutions. They include: the various optics clusters in the Asia-Pacific region, Europe and North America; the international professional societies; and organizations that provide photonics and engineering education materials. The support and collaboration of this network will be a key factor for the success of NAPET. In particular, we will actively participate in the development of the Global Photonics Education Network (GPEN) proposed recently. As a national body, NAPET will be one of the national nodes within this education network.

\section{Concluding Remarks}

The development of an integrated education and training system in optics and photonics is vital to the continual development of the workforce and the sustainable growth of the photonics industry in Singapore. In particular, the development of new, innovative photonics education and training programs will also enrich science education in the schools in Singapore. The formation of NAPET has enabled the whole optics community to work together to 
achieving these goals. The collaboration with local and international organizations will be a key factor to ensuring the success in this endeavor.

\section{References}

[1] T. K. Lim, "Workforce Education and Manpower Development: a Road Map for Singapore", Proc. SPIE, Vol. 4588 (Proceedings of the $7^{\text {th }}$ International Conference on Education and Training in Optics and Photonics, 26-30 November 2001, Singapore), pp. 354-361 (2002).

[2] Singapore Ministry of Education website: http://www.moe.edu.sg/

[3] Singapore Economic Development Board (EDB) website: http://www.edb.gov.sg/

[4] T. K. Lim, "Education and Training in Optics and Photonics: a Global Perspective", Forum on Education and Training in Optics and Photonics, 2 December 1999, Shangri-La Hotel, Singapore.

[5] T. K. Lim, "Education and Training in Optics and Photonics: an Action Plan for Singapore", 3rd Singapore Optics/Photonics Forum, 19 July 2000, Marina Mandarin Hotel, Singapore.

[6] T. K. Lim, "Workforce Education and Manpower Development: a Road Map for Singapore", $4^{\text {th }}$ Singapore Optics/Photonics Forum, 25 July 2001, Marina Mandarin Hotel, Singapore.

[7] T. K. Lim, "Developing Photonics Education”, SPIE OE Magazine, August 2003, p. 47.

[8] Nanyang Technological University (NTU) website: http://www.ntu.edu.sg 
Table 1

Key Events in the Development of Photonics in Singapore

[1994-2003]

\begin{tabular}{|c|c|c|}
\hline Year & Event & $\begin{array}{l}\text { Organizations/Institutions } \\
\text { Involved }\end{array}$ \\
\hline 1994 & $\begin{array}{l}\text { Photonics Research Group formed } \\
\text { [Founding Member] }\end{array}$ & School of EEE, NTU \\
\hline 1995 & $\begin{array}{l}\text { SPIE Singapore Chapter formed } \\
\text { [Founding Chair] }\end{array}$ & $\begin{array}{l}\text { SPIE members in NTU, NUS, other } \\
\text { institutions, and the industry }\end{array}$ \\
\hline \multirow[t]{2}{*}{1998} & $\begin{array}{l}\text { Inauguration of Singapore Optics/Photonics Forum } \\
\text { [Co-Chair, Organizing Committee] }\end{array}$ & $\begin{array}{l}\text { Organized by PSB and } \\
\text { SPIE Singapore Chapter }\end{array}$ \\
\hline & $\begin{array}{c}\text { UNIDO-ICS Training Course on Photonics } \\
\text { Technology for the } 21 \text { st Century: Principles } \\
\text { and Applications } \\
\text { [Coordinator, Chair of Organizing Committee, and } \\
\text { an Instructor] }\end{array}$ & $\begin{array}{c}\text { School of EEE, NTU; United Nations Industrial } \\
\text { Development Office (UNIDO); and } \\
\text { International Centre for Science and High } \\
\text { Technology (ICS) }\end{array}$ \\
\hline \multirow[t]{2}{*}{1999} & $\begin{array}{c}\text { Forum on Education and Training in Optics and } \\
\text { Photonics (ETOP) } \\
\text { [Organizer and Speaker] }\end{array}$ & $\begin{array}{c}\text { School of EEE, NTU; SPIE Singapore Chapter; } \\
\text { EDB; PSB; other education institutions; and } \\
\text { industry }\end{array}$ \\
\hline & $\begin{array}{c}\text { The International Symposium on Photonics and } \\
\text { Applications (ISPA '99) } \\
\text { [Co-Chair, Organizing Committee] }\end{array}$ & $\begin{array}{l}\text { Organized by School of EEE, NTU, SPIE, and } \\
\text { SPIE Singapore Chapter }\end{array}$ \\
\hline \multirow[t]{3}{*}{2000} & $\begin{array}{l}\text { Photonics Learning \& Research Centre established } \\
\text { [Advisor] }\end{array}$ & The Chinese High School \\
\hline & Photonics Exploratory Lab established & Raffles Institution \\
\hline & $\begin{array}{c}\text { Singapore Centre of Photonics Excellence (SCOPE) } \\
\text { formed } \\
\text { [Founding Member }]\end{array}$ & $\begin{array}{c}\text { EDB, PSB, NSTB, NTU, NUS, Gintic, DSI, } \\
\text { IME, IMRE }\end{array}$ \\
\hline \multirow[t]{3}{*}{2001} & $\begin{array}{c}\text { Photonics Association (Singapore) [PA(S)] officially } \\
\text { formed } \\
\text { [Founding Member; Chair, Education Committee] }\end{array}$ & $\begin{array}{l}\text { Optics and photonics companies, Ngee Ann } \\
\text { Polytechnics, and SPIE Singapore Chapter }\end{array}$ \\
\hline & $\begin{array}{c}\text { ETOP 2001: The } 7^{\text {th }} \text { International Conference on } \\
\text { Education and Training in Optics and Photonics } \\
\text { [Conference Chair; Chair of Local Organizing } \\
\text { Committee] }\end{array}$ & $\begin{array}{l}\text { Organized by School of EEE, NTU, SPIE, and } \\
\text { SPIE Singapore Chapter }\end{array}$ \\
\hline & $\begin{array}{c}\text { ISPA 2001: The } 2^{\text {nd }} \text { International Symposium on } \\
\text { Photonics and Applications }\end{array}$ & $\begin{array}{l}\text { Organized by School of EEE, NTU, SPIE, and } \\
\text { SPIE Singapore Chapter }\end{array}$ \\
\hline 2002 & $\begin{array}{c}5^{\text {th }} \text { Singapore Optics/Photonics Forum } \\
\text { \& Photonics World } 2002 \\
\text { [Member, Organizing Committee] }\end{array}$ & Organized by PA(S) and HQ Link Pte. Ltd \\
\hline \multirow[t]{2}{*}{2003} & $\begin{array}{l}\text { National Alliance for Photonics Education and } \\
\text { Training (NAPET) formed } \\
\text { [Founder and Chair, Coordination Committee] }\end{array}$ & $\begin{array}{c}\text { An alliance of all education institutions, } \\
\text { government bodies, professional societies, and } \\
\text { the industry }\end{array}$ \\
\hline & $\begin{array}{c}\text { Singapore-Australia Photonics School } \\
\text { [General Chair, Local Organizing Committee] }\end{array}$ & $\begin{array}{c}\text { Organized by School of EEE, NTU, PA(S), } \\
\text { NAPET, and Australian Photonics Cooperative } \\
\text { Research Centre (CRC) }\end{array}$ \\
\hline
\end{tabular}


The Education System

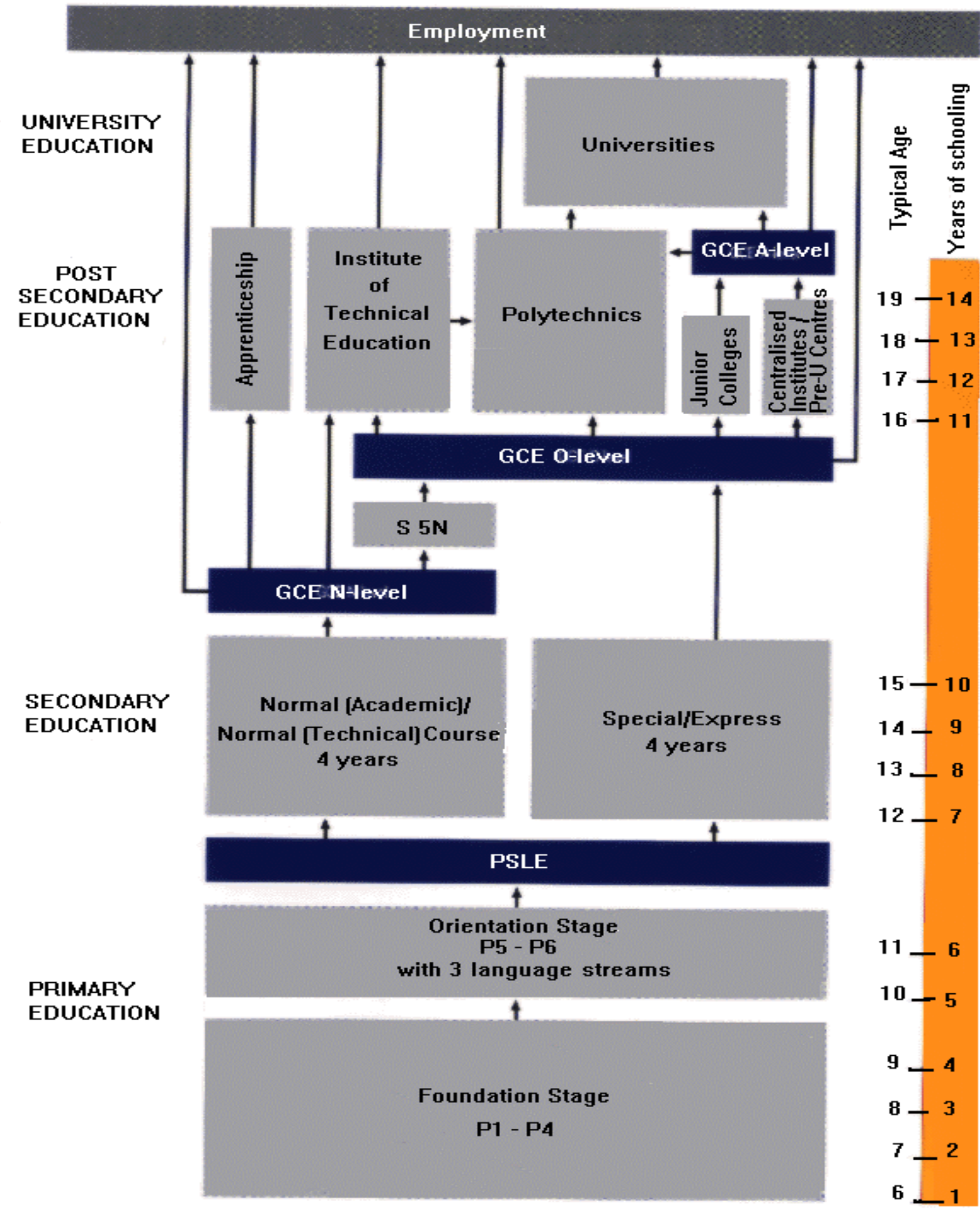

Figure 1 Flowchart of the Singapore education system [2] 